\title{
VERIFIKASI BIOLOGIS DAN KESEHATAN REPRODUKSI CALON MEMPELAI PRA PERKAWINAN DALAM PERSPEKTIF HUKUM ISLAM
}

\author{
Fitriyani \\ UIN Syarif Hidayatullah Jakarta DPK Universitas Nahdhatul Ulama Jakarta \\ Email: fitriyanispsuinjkt@gmail.com
}

\begin{abstract}
This study describes the biological verification and reproductive health of prospective pre-marriage brides in the perspective of Islamic law, and covers Islamic insights regarding the verification of biological and reproductive health of premarriage brides, and the law to conduct biological verification and reproductive health for pre-marriage brides in legal perspective Islam.

The case that took place in Bulukumba on September 17, 2017 was related to biological forgery between Syarifah Nurul Husna (20 years) and Rahmat Yani (28 years old) a woman from Erelebu Hamlet, Eka Tiro Village, Bontotiro District, Bulukumba Regency. Apparently married to fellow women, he was involved with same-sex marriage. Revealed when the first night after the wedding ceremony took place, finally arrived where the moment of the two lovebirds got together in the first night. Suddenly Nurul Husna screamed and ran out of her room, she was crying out unconsciously knowing that Rahmat Yani was actually a woman. Syarifa Nurul Husna's family did not remain silent over the incident that happened to her daughter, they then made a vote on her daughter-in-law's identity. After doing the checkup, he finally found out if Rahmat Yani was Rahmayani according to the residents of Herlang Hamlet, from the village of Rahmat Yani.

For the sake of the sanctity of the marriage institution, similar events are expected not to occur again in the future. For this reason, a solution needs to be formulated, including fixing civil administration regulations. This study seeks to discuss one solution, which includes verification of identity and reproductive health as one administrative requirement for marriage. If it refers to the quantity of cases, this idea might be considered as an excessive response. However, when viewed from the classical fiqh perspective, this has been exemplified in the early days of the development of Islamic Law. Presupposition cases born from the leaders of four popular schools indicate that there is no need to wait for cases to establish the law. For example, the priests of the school of thought have spoken and determined the legal consequences of a clogged vagina or a penis being cut off for marital survival

This research is a descriptive research (library research) with a type of qualitative research, using a legal approach (formal juridical), a case approach, a fiqh approach and a psychological approach. The theory used is Maqasyid syariah related to the maintenance of offspring popularized by As-Sya tiby and the benefit theory that was popularized by at-Tufi.
\end{abstract}

Keywords: Verification, Bride Biological Candidates, Islamic Law. 
Fitriyani

\begin{abstract}
Abstrak
Penelitian ini memaparkan mengenai Verifikasi biologis dan kesehatan reproduksi calon mempelai pra perkawinan dalam presfektif hukum Islam, dan mencakup tentang wawasan Islam mengenai verifikasi biologis dan kesehatan reproduksi calon mempelai pra perkawinan, serta hukum melakukan verifikasi biologis dan kesehatan reproduksi bagi calon pengantin pra perkawinan dalam presfektif hukum Islam.

Kasus yang terjadi di Bulukumba pada tanggal 17 September 2017 terkait dengan pemalsuan biologis antara Syarifah Nurul Husna (20 tahun) dan Rahmat Yani (28 tahun) perempuan asal Dusun Erelebu, Kelurahan Eka Tiro, Kecamatan Bontotiro, Kabupaten Bulukumba. Ternyata menikah dengan sesama perempuan, dia terlibat dengan perkawinan sesama jenis. Terungkap pada saat malam pertama setelah pesta pernikahan berlangsung, akhirnya tiba dimana momen dua sejoli dapat berduaan di malam pertama. Tiba-tiba Nurul Husna menjerit dan berlari keluar kamarnya, dia menagis sejadi-jadinya mengetahui bahwa Rahmat Yani sebenarnya adalah seorang perempuan. Pihak keluarga Syarifa Nurul Husna tidak diam atas kejadian yang menimpa putrinya, mereka kemudian melakukan korscek atas identitas menantunya tersebut. Setelah melakukan kroscek, akhirnya dia mengetahui jika Rahmat Yani adalah Rahmayani menurut warga Dusun Herlang, asal kampung Rahmat Yani.

Demi kesucian lembaga perkawinan, kejadian serupa diharapkan tidak terjadi lagi di masa depan. Untuk itu, perlu dirumuskan solusi, termasuk membenahi regulasi administrasi keperdataan. Penelitian ini berusaha mendiskusikan satu solusi, yakni memasukkan verifikasi identitas dan kesehatan reproduksi sebagai salah satu syarat administratif perkawinan. Jika merujuk pada kuantitas kasusnya, boleh jadi gagasan ini dianggap sebagai respons berlebihan. Akan tetapi, jika dilihat dari kacamata fikih klasik, hal ini justru telah dicontohkan pada masa awal perkembangan Hukum Islam. Kasus-kasus pengandaian yang lahir dari para pemuka empat mazhab populer mengisyaratkan bahwa tidak perlu menunggu terjadinya kasus untuk menetapkan hukum. Misalnya, para imam mazhab telah berbicara dan menetapkan akibat hukum vagina yang tersumbat atau penis yang terpotong terhadap kelangsungan perkawinan

Penelitian ini merupakan penelitian (library research) deskriptif dengan jenis penelitian kualitatif, menggunakan pendekatan perundang-undangan (yuridis formal), pendekatan kasus, pendekatan fikih dan pendekatan psikologis. Adapun teori yang digunakan adalah teori Maqashid syariah terkait dengan pemeliharaan keturunan yang dipopulerkan oleh As-Syatiby dan teori Kemaslahatan yang dipopulerkan oleh at-Tufi.
\end{abstract}

Kata Kunci: Verifikasi, Biologis Calon Mempelai, Hukum Islam.

\title{
A. Pendahuluan
}

Dibelakangan ini sering kita saksikan berita di media sosial perkawinan sejenis atau yang dikenal dengan istilah LGBT $^{1}$ dan

\footnotetext{
${ }^{1}$ LGBT adalah akronim dari "lesbian, gay, biseksual, dan transgender". Istilah ini digunakan semenjak tahun 1990-an dan menggantikan frasa "komunitas gay" karena istilah ini lebih mewakili kelompok-kelompok yang telah disebutkan.
} 
Verifikasi Biologis Dan Kesehatan Reproduksi Calon Mempelai Pra Perkawinana Dalam Perspektif Hukum Islam

maraknya perceraian disebabkan karena beberapa hal termasuk karena pasangan suami istri tersebut tidak dapat memberikan keturunan (mandul) $^{2}$ baik itu istri yang mandul ataupun suami yang impoten, sehingga jika seorang perempuannya yang mandul, maka membuka peluang untuk seorang laki-laki berpoligami karena alasan tidak bisanya seorang istri memberikan keturunan ${ }^{3}$.

Akronim ini dibuat dengan tujuan untuk menekankan keanekaragaman "budaya yang berdasarkan identitas seksualitas dan gender". Kadang-kadang istilah LGBT digunakan untuk semua orang yang tidak heteroseksual, bukan hanya homoseksual, biseksual, atau transgender. Maka dari itu, seringkali huruf $Q$ ditambahkan agar queer dan orang-orang yang masih mempertanyakan identitas seksual mereka juga terwakili (contoh. "LGBTQ" atau "GLBTQ", tercatat semenjak tahun 1996. Istilah LGBT sangat banyak digunakan untuk penunjukkan diri. Istilah ini juga digunakan oleh mayoritas komunitas dan media yang berbasis identitas seksualitas dan gender di Amerika Serikat dan beberapa negara berbahasa Inggris lainnya. Tidak semua kelompok yang disebutkan setuju dengan akronim ini. Beberapa orang dalam kelompok yang disebutkan merasa tidak berhubungan dengan kelompok lain dan tidak menyukai penyeragaman ini. Beberapa orang menyatakan bahwa pergerakan transgender dan transeksual itu tidak sama dengan pergerakan kaum "LGB".Terdapat pula keyakinan "separatisme lesbian\& gay", yang meyakini bahwa kelompok lesbian dan gay harus dipisah satu sama lain. Selain itu, ada juga yang tidak menggunakan istilah ini karena mereka merasa bahwa: akronim ini terlalu politically correct; akronim LGBT merupakan sebuah upaya untuk mengategorikan berbagai kelompok dalam satu wilayah abu-abu; dan penggunaan akronim ini menandakan bahwa isu dan prioritas kelompok yang diwakili diberikan perhatian yang setara. Di sisi lain, kaum interseksingin dimasukkan ke dalam kelompok LGBT untuk membentuk "LGBTI" (tercatat sejak tahun 1999). Akronim "LGBTI" digunakan dalam The Activist's Guide of The Yogyakarta Principles in Action. Lihat https://id.wikipedia.org/wiki/LGBT.

${ }^{2}$ Bagi wanita, arti mandul ialah tidak mampu hamil karena indung telur mengalami kerusakan sehingga tidak mampu memproduksi sel telur. Sementara, arti mandul bagi pria ialah tidak mampu menghasilkan kehamilan karena buah pelir tidak dapat memproduksi sel spermatozoa sama sekali. Baik pria maupun wanita yang mandul tetap mempunyai fungsi seksual yang normal. Tetapi sebagian orang yang mengetahui dirinya mandul kemudian mengalami gangguan fungsi seksual sebagai akibat hambatan psikis karena menyadari kekurangan yang dialaminya. Tetapi istilah mandul acapkali digunakan untuk menyebut pasangan suami istri yang belum mempunyai anak walaupun telah lama menikah. Padahal pasangan suami istri yang belum mempunyai anak setelah lama menikah tidak selalu mengalami kemandulan. Yang lebih banyak terjadi adalah pasangan yang infertil atau pasangan yang tidak subur. Di Indonesia diduga terdapat sekitar 10-15 persen pasangan suami istri yang mengalami hambatan hamil, meliputi pasangan mandul dan infertil. http://www.resep.web.id/kehamilan/apa-yang-dimaksud-dengan-mandul.htm.

${ }^{3}$ Sebagiamana yang terdapat dalam Undang-undang No. 1 Tahun 1974 tentang Perkawinan pasal 4 ayat (2) terkait alasan seorang suami bisa beristri lebih dari satu 
Fitriyani

Oleh karena itu, menurut peneliti bahwa sebelum melangsungkan perkawinan perlu diadakan verifikasi biologis dan verifikasi kesehatan reproduksi baik dari calon mempelai wanita maupun mempelai lakilaki, sehingga dikemudian hari tidak terjadi kegagalan dalam membinah mahligai rumah tangga.

Contoh kasus yang terjadi di Bulukumba pada tanggal 17 September 2017 terkait dengan pemalsuan biologis antara Syarifah Nurul Husna (20 tahun) dan Rahmat Yani (28 tahun) perempuan asal Dusun Erelebu, Kelurahan Eka Tiro, Kecamatan Bontotiro, Kabupaten Bulukumba. Ternyata menikah dengan sesama perempuan, dia terlibat dengan perkawinan sesama jenis. Terungkap pada saat malam pertama setelah persta pernikahan berlangsung, akhirnya tiba dimana momen dua sejoli dapat berduaan dimalam pertama. Tiba-tiba Nurul Husna menjerit dan berlari keluar kamarnya, dia menagis sejadi-jadinya mengetahui bahwa Rahmat Yani sebenarnya adalah seorang perempuan. Pihak keluarga Syarifa Nurul Husna tidak diam atas kejadian yang menimpa putrinya, mereka kemudian melakukan korscek atas identitas menantunya tersebut. Setelah melakukan kroscek, akhirnya dia mengetahui jika Rahmat Yani adalah Rahmayani menurut warga Dusun Herlang, asal kampung Rahmat Yani. ${ }^{4}$

Kesakralan pernikahan di Tanah Air kadang ternodai aksi pelanggaran hukum. Salah satunya karena adanya pernikahan sejenis. Hingga saat ini, pemerintah Indonesia tidak melegalkan pernikahan sejenis antara perempuan dengan perempuan atau laki-laki dengan lakilaki. Meskipun termasuk pelanggaran hukum, ada saja warga yang nekat melakukannya. Sejumlah pernikahan sejenis terjadi di beberapa daerah. Berbagai cara dilakukan pasangan sejenis ini untuk mengukuhkan cinta terlarang mereka ke jenjang pernikahan. Baru-baru ini, pasangan sejenis perempuan asal Purworejo nekat memalsukan identitas untuk mendapatkan buku nikah dari Kantor Urusan Agama

disebabkan karena: a) istri tidak dapat menjalankan kewajibannya sebagai istri, b) istri mendapat cacat badan atau penyakit yang tidak dapat disembuhkan, c) istri tidak dapat memberikan keturunan. Lihat Undang-Undang No. 1 Tahun 1974 tentang Perkawinan dilengkapi dengan Kompilasi Hukum Islam, (Cet; tt: WIPRESS, 2007), h. 2 .

${ }^{4}$ http://www.tribunnews.com/regional/2017/09/29/hal-seputar-pernikahansejenis-di-bulukumba-jeritan-malam-pertama-hingga-uang-panaik-puluhanjuta?page $=2$ 
(KUA). Saat ini, polisi masih mengusut kasus tersebut dengan tersangka calon mempelai pria yang memalsukan identitasnya. ${ }^{5}$

Demi kesucian lembaga perkawinan, kejadian serupa diharapkan tidak terjadi lagi di masa depan. Untuk itu, perlu dirumuskan solusi, termasuk membenahi regulasi administrasi keperdataan. Penelitian ini berusaha mendiskusikan satu solusi, yakni memasukkan verifikasi identitas dan kesehatan reproduksi sebagai salah satu syarat administratif perkawinan. Jika merujuk pada kuantitas kasusnya, boleh jadi gagasan ini dianggap sebagai respons berlebihan. Akan tetapi, jika dilihat dari kacamata fikih klasik, hal ini justru telah dicontohkan pada masa awal perkembangan Hukum Islam. Kasus-kasus pengandaian yang lahir dari para pemuka empat mazhab populer mengisyaratkan bahwa tidak perlu menunggu terjadinya kasus untuk menetapkan hukum. Misalnya, para imam mazhab telah berbicara dan menetapkan akibat hukum vagina yang tersumbat atau penis yang terpotong terhadap kelangsungan perkawinan. ${ }^{6}$ Kasus-kasus seperti ini hampir tidak ditemukan dalam realitas, termasuk pada masa kehidupan mereka, tetapi tetap mereka kaji dengan melihat adanya potensi hal tersebut terjadi.

\section{B. Pembahasan}

\section{Pemalsuan Identitas Calon Mempelai Pra Pernikahan}

Sejatinya pernikahan sejenis dilarang oleh Undang-Undang Nomor 1 Tahun 1974 tentang Perkawinan. Di mana, pernikahan harus dilakukan antara laki-laki dan perempuan. ${ }^{7}$ Dan pada dasarnya pernikahan yang dilakukan dengan sesama jenis jelas melanggar hukum Islam dan hukum Negara.

Perkawinan atau pernikahan, ${ }^{8}$ adalah sebuah perkara yang memiliki banyak makna dan tujuan bagi manusia dan kemanusiaan itu

\footnotetext{
${ }^{5} \mathrm{http} / / /$ regional.liputan6.com/read/3084644/pernikahan-sejenis-yangmenghebohkan-di-berbagai-daerah

${ }^{6}$ Pembahasan mengenai hal ini dapat dirujuk antara lain pada Kitab al-Mabsuth karya al-Sarakhsî, al-Mudawwanah karya Sahnun, dan al-Umm karya Imam asSyâfi'i.

${ }^{7}$ https://news.okezone.com/read/2017/09/29/337/1785268/catat-komnasperempuan-pernikahan-sejenis-di-indonesia-langgar-uu-perkawinan.

${ }^{8}$ Perkawinan atau pernikahan berasal dari kata kawin, nikah, yang berarti perjanjian antara dua orang (laki-laki dan wanita) yang mau menjadi suami istri secara resmi dan sah, lihat J.S dan Sutan Mohammad Zain, Kamus Bahasa Indonesia, (Cet. I; Pustaka Sinar Harapan, Jakarta: 2001), h. 943.
} 
sendiri. Tidak terkecuali di Indonesia. Sacara umum perkawinan adalah sebuah perilaku turun menurun dari umat manusia, sebagai sarana yang dipandang baik dan benar, untuk melanjutkan proses regenerasi dan kesinambunhgan hidup dan kehidupan umat manusia itu sendiri. Perkawinan merupakan ikatan yang sangat suci dan kokoh antara sepasang anak manusia, yang diharapkan akan mampu menjalin sebuah ikatan lahir dan batin antara suami istri sebagai modal untuk menciptakan rumah tangga yang sakinah mawaddah wa rahma yaitu keluarga yang bahagia dan di ridhoi Allah swt., Oleh karena itu langgengnya sebuah perkawinan merupakan suatu tujuan yang sangat diinginkan Islam. ${ }^{9}$

Terlepas dari keharamannya, pemalsuan identitas biologis dengan modus untuk menikah sesama jenis nyaris tidak pernah terbayangkan. Ini karena persepsi mengenai perkawinan didasarkan terutama pada tujuan perkawinan, sifat perkawinan sebagai hal yang sakral, serta perbedaan mencolok antara laki-laki dan perempuan. Tujuan perkawinan adalah mengabsahkan hubungan seks dan melanjutkan keturunan. Keduanya tidak mungkin tercapai melalui perkawinan sejenis. Disamping itu, perkawinan adalah peristiwa sakral yang lazimnya dilaksanakan di depan ratusan bahkan ribuan pasang mata. Sedangkan secara umum, laki-laki dan perempuan dapat dibedakan meski didasarkan pada penglihatan selintas. Ketika mengenakan pakaian yang sama pun, laki-laki dan perempuan tetap dapat dibedakan melalui sejumlah tanda fisiknya. Bahkan hanya dengan mendengar suara, laki-laki dan perempuan dapat dibedakan secara mudah karena mereka memiliki warna suara (timbre) yang berbeda. ${ }^{10}$

\footnotetext{
${ }^{9}$ Menurut Abd Rahman al-Jaziri, kata nikah (kawin) dapat didekat dengan tiga aspek pengertian (makna), yakni makna lughawi (etimologis), makna ushuli (syar'i) dan makna Fiqh (hukum), lihat dalam buku Abdu al-Rahman al-Jauzairi, al-Fiqh 'Ala Mazahib al-Arba'ah, jilid 4 (Bairut: Lubanan, 1990), h. 2. Dalam UndangUndang No 1 Tahun 1974 tentang Perkawinan Pasal, defenisi perkawinan yaitu: ikatan lahir dan batin antara seorang pria dan seorang wanita sebagai suami istri dengan tujuan membentuk keluarga (rumah tangga) yang bahagia dan kekal berdasarkan Ketuhanan Yang Maha Esa,. Dalam istilah fiqh, nikah berarti sebuah akad/perjanjian yang menghalalkan hubungan suami istri antara laki-laki dan perempuan, untuk melanjutkan kehidupan dalam proses regenerasi, dengan sagala hak dan kewajiban yang terkandung di dalalmnya bagi keduanya, lihat Ahmad Ghanduri, al-Ahwal al-Syahshiyah fi Tasyri al-Islami, (Cet. IV; Beirut: Maktabah al-Falah, 2001), h. 33.

${ }^{10}$ Perbedaan antara pria dan wanita dapat dilihat dari ciri-ciri fisik maupun psikis yang dimilikinya. Ciri-ciri fisik pria di antaranya mempunyai lebaran bahu
} 
Verifikasi Biologis Dan Kesehatan Reproduksi Calon Mempelai Pra Perkawinana Dalam Perspektif Hukum Islam

Bentuk pemalsuan identitas calon mempelai masih banyak, apalagi menyangkut identitas sosial seperti menyatakan diri masih perjaka/gadis padahal sudah berstatus duda/janda, mengaku bekerja padahal pengangguran, pengakuan alamat yang tidak benar dan seterusnya.

Apapun bentuk dan motifnya, pemalsuan identitas merupakan bukti kuat masih adanya titik lemah dalam sistem administrasi keperdataan Islam yang kita miliki sehingga menuntut upaya nyata untuk melakukan pembenahan. ${ }^{11}$ Karena itu, dapat dimaklumi jika sebuah media massa menulis, "Pernikahan terlarang Muhammad Umar dengan Fransiska Anastasya Octaviany alias Rahmat Sulistyo menjadi berita menggetirkan, ini juga menjadi bukti administrasi negara kacau balau".

\section{Potensi dan Motif Pemalsuan Identitas Calon Mempelai Pra Pernikahan}

Potensi dan motif pemalsuan identitas dapat dilakukan oleh lakilaki maupun perempuan. Dalam kasus Rahmat yani dan Syarifah Nurul Husna, pemalsuan identitas dilakukan oleh Rahmat Yani terhadap Syarifa Nurul Husna, Rahmat Yani ternyata adalah seorang yang berjenis kelamin permpuan yang sebenarnya bernama Rahmayani yang berasal dari Dusun Herlang daerah Bulumba.

Siapa pun mereka, diasumsikan bahwa pemalsuan identitas biologis dilakukan oleh penyandang prilaku seks yang menyimpang: gay dan lesbian. Gay ${ }^{12}$ adalah laki-laki yang mempunyai ketertarikan

lebih besar dari panggul, payudara tidak berkembang seperti pada wanita, suara keras atau berat, glutea (pantat) sedikit berisi atau tidak sama sekali. Ciri-ciri fisik wanita diantaranya mempunyai lebaran bahu lebih kecil dari panggul, payudara yang berkembang mulai dari masa pubertas hingga dewasa, suara halus atau lembut atau merdu, glutea (pantat) yang lebih berisi.

${ }^{11}$ Alimin Mesra, Verifikasi Identitas Biologis Menjelang Perkawinan dalam Presfektif Fikih. Dalam jurnal Hukum Islam Fakultas Syariah UIN Syarif Hidayatullah Jakarta: Ahkam Vol XII, No. 2 Juli, Tahun 2012. h. 28.

${ }^{12}$ Gay Istilah gay digunakan secara umum untuk menggambarkan seorang pria yang tertarik secara seksual dengan pria lain dan menunjukkan komunitas yang berkembang diantara orang-orang yang memiliki orientasi seksual yang sama. Caroll (2005) mengatakan bahwa orientasi seksual merupakan ketertarikan seseorang pada jenis kelamin tertentu secara emosional, fisik, seksual dan cinta. Caroll kemudian menambahkan bahwa teori-teori yang berhubungan dengan orientasi seksual dapat dibagi dalam dua tipe yang dasar: yaitu essential dan constructionist. Pada paham esentialisme menekankan bahwa homoseksual secara pembawaan berbeda dengan 
pada laki-laki yang sering disebut dengan homoseksual, ${ }^{13}$ sementara lesbi ${ }^{14}$ adalah perempuan yang tertarik pada sesama perempuan. Kelompok inilah yang berpotensi melakukan pemalsuan identitas biologis untuk menikah dengan pasangan sesama jenis yang dicintainya. Terlepas dari perdebatan apakah perilaku seks menyimpang seperti itu sebagai kodrat atau bukan, harus diakui bahwa manusia dengan perilaku yang demikian selalu ada dalam sejarah. Pada satu bagian, Alquran menyebutkan keberadaan mereka, tepatnya pada masa Nabi Luth As. ${ }^{15}$ Hanya saja tidak ada data akurat tentang jumlah populasi sebab secara social keberadaan mereka tidak diakui di satu sisi sehingga mereka cenderung merahasiakan kecenderungannya.

Prilaku seks menyimpang, tidak mesti bawaan sejak lahir. Pengalaman hidup seseorang dapat menyebabkan terjadinya perubahan perilaku seks. Hal ini terkesan dialami oleh Rahmat Sulistiyo, laki-laki yang mengaku sebagai Fransisca Anastasia mulanya adalah seorang lakilaki normal. Buktinya, sebelum menikah dengan Umar, ia sempat berpacaran dengan seorang perempuan. Putus cinta yang dialami dengan pacarnya itu menyebabkan terjadi perubahan prilaku. Motivasi pemalsuan identitas dalam perkawinan dapat dijelaskan melalui pendekatan psikologis. Sebagaimana manusia normal, mereka adalah manusia yang juga memiliki perasaan cinta. Mereka memiliki dan butuh kasih sayang, sehingga mencari sasaran kepada siapa rasa itu ia berikan sekaligus dari mana kebutuhan itu ia dapatkan. Dibanding dengan laki-laki dan perempuan normal, perbedaannya hanya satu, yakni memilih sesama jenis untuk memberi dan mendapatkan cinta/ kasih sayang. Konsekuensi-konsekuensi psikologis yang lahir dari perasaan itu seperti kesetiaan, kepedulian, ketidaksiapan untuk

heteroseksual, hasil dari faktor biologis dan proses perkembangan. Teori essential mula-mula mengimplikasikan bahwa homoseksualitas merupakan sebuah abnormalitas dalam perkembangan yang memberikan kontribusi bahwa homoseksual ini adalah suatu penyakit. Sedangkan paham constructionist sebaliknya menekankan bahwa homoseksulitas merupakan suatu peran sosial yang telah berkembang secara berbeda dalam kebudayaan yang berbeda dan waktu yang berbeda juga dan untuk ini dapat dikatakan bahwa homoseksualitas secara pembawaan, tidak berbeda dengan heteroseksualitas. http://www.landasanteori.com/2015/09/pengertian-gay-jenis-tipehubungan.html

${ }^{13}$ Homoseksual adalah laki-laki mempunyai ketertarikan pada sesama laki-laki.

${ }^{14}$ Lesbian perempuan yang mempunyai ketertarikan pada sesama perempuan.

${ }^{15}$ Alimin Mesra, Verifikasi Identitas Biologis Menjelang Perkawinan dalam Presfektif Fikih. Dalam Jurnal Hukum Islam Fakultas Syariah UIN Syarif Hidayatullah Jakarta: Ahkam Vol XII, No. 2 Juli, Tahun 2012. h. 28. 
Verifikasi Biologis Dan Kesehatan Reproduksi Calon Mempelai Pra Perkawinana Dalam Perspektif Hukum Islam

berpisah/dipisahkan, kesediaan berkorban dan lain-lain relatif sama. Artinya, jika laki-laki dan perempuan normal siap mengorbankan apa saja atas nama cinta, mereka pun mempunyai kesiapan yang sama.

Teori bahwa cinta adalah motivasi yang paling kuat untuk melakukan sesuatu dapat menjelaskan hal ini. Kebenaran teori ini dapat dibuktikan dengan fenomena- fenomena yang sangat lumrah di dalam kehidupan manusia. Kesediaan melakukan apa saja untuk anak dan isteri muncul karena cinta seorang ayah/suami bagi mereka. Juga dengan penjelasan-penjelasan religious seperti kesediaan menjadi syuhada atau memperbanyak ibadah karena kecintaan kepada Allah. Penyelewengan Zulaikha, yakni menggoda Yusuf di belakang suaminya, Photipar, juga karena motif cinta, keputusan Rabi'ah alAdawiyah menolak kehadiran semua laki-laki yang melamarnya juga karena motivasi cinta. Sekali lagi, teori tersebut tampak dapat menjelaskan betapa perbuatan yang melanggar pakem sosial dan norma agama itu dapat terjadi. Asmara yang membara yang dialami oleh dua anak manusia telah melahirkan ragam pelanggaran norma sosial dan agama. Betapa perkawinan lari itu dianggap aib oleh masyarakat Indonesia pada umumnya, tetap saja sering dilakukan oleh pasangan muda-mudi yang dimabuk asmara demi memertahankan cinta. Selain itu, sejumlah kisah cinta yang melegenda juga dapat membantu memahami kemungkinan terjadinya kasus-kasus yang tidak terpikirkan sekalipun. Pokoknya, realitas menunjukkan bahwa pengatasnamaan cinta seringkali menjadi dasar untuk melakukan kreasi, kiatkiat, serta modus-modus baru. Pada tingkat tertentu, kreasi dan modus yang dilahirkan itu bahkan menabrak nilai-nilai luhur, bahkan sampai pada kodrat dan aturan ilahi yang diyakini oleh pelakunya sendiri. Demikianlah cinta, perasaan yang dimiliki oleh manusia itu dapat terwujud dalam ekspresi dan tindakan yang berbeda. Dalam kondisi terhalang, ia akan berusaha mencari jalan agar menuju "keabadian". Keterpautan hati yang mereka klaim dengan ungkapan "kami saling mencintai" boleh jadi mengantar pada titik diawalinya rekayasa pemalsuan identitas. Hal ini sangat mungkin sebab di satu sisi mereka merasakan dirinya tidak mungkin dipisahkan dan pada saat yang sama semua jalan di sekelilingnya tertutup, norma agamamenyatakan haram, norma hukum tak membenarkan, masyarakat umum membencinya. Untuk itu, satusatunya jalan yang dapat menyelamatkan mereka adalah salah seorang harus melakukan pemalsuan identitas, agar di mata publik perkawinan berlangsung secara wajar. 


\section{Verifikasi Indentitas Biologis dan Kesehatan Reproduksi Calon Mempelai Pra Pernikahan Presfektif Hukum Islam}

Indonesia adalah salah satu negara yang menganut teori normalitas, sama dengan sikap negara yang masyarakatnya secara umum memegang teguh ajaran agama. Karena itu, gay, lesbi, dan turunannya termasuk pernikahan sesama jenis melalui modus pemalsuan identitas tidak mendapatkan tempat. Konsisten dengan itu, negara berkepentingan untuk menutup celah terjadinya pemalsuan identitas biologis dalam perkawinan. Karenanya, ketika terjadi pelanggaran, apalagi telah berulang kali, semestinya negara melakukan kajian atas pranata hukum yang mengaturnya. Kaitannya dengan pemalsuan identitas bologis, negara harus merumuskan dan menetapkan payung hukum yang memberi kewenangan kepada pihak tertentu untuk melakukan verifikasi identitas biologis. Verifikasi yang dimaksud adalah proses untuk memastikan kesamaan antara identitas biologis formal identitas biologis yang tertera pada KTP dan dokumen lainnyadengan identitas biologis faktual seakurat mungkin. Payung hukum yang dimaksud pada tingkat tertentu memberi kewenangan di bawah sumpah untuk mengabsahkan jenis kelamin laki-laki dengan melihat penis dan menetapkan perempuan sebagai perempuan dengan melihat vaginanya secara langsung. Pemalsuan identitas bukan problem tunggal terkait perkawinan, masih banyak masalah lain seperti disfungsi organ seksual, penyakit menular seksual, dan lainlain. Karena itu, dalam rumusan dan penetapannya, payung hukum yang dimaksud memberi kewenangan yang lebih luas dan detail sampai pada diagnosis untuk mengetahui kondisi dan kesehatan fungsi alat reproduksi masingmasing mempelai. Artinya, verifikasi yang dilakukan meliputi klarifikasi identitas biologis, fungsi dan sterilitas organ reproduksi, virginity, dan lain-lain. Pertanyaannya kemudian, apakah ada dasar teologis untuk melakukan itu? Ini penting, sebab upaya pembaruan hukum di Indonesia, lazim mendapat resistensi atas nama agama.

Terhadap gagasan di atas, resistensi mungkin muncul dari masyarakat dengan argumen melampaui batas etika, melanggar ketentuan agama, atau tidak mungkin dilakukan (muluk-muluk). Akan tetapi sejumlah alasan penolakan ini dapat dibantah dengan mengajukan sejumlah argumen yang merujuk pada dalil agama seperti Hadis-hadis Nabi, sejumlah kaidah-kaidah Ushul yang disepakati oleh para ulama, serta pemikiran hukum para fukaha klasik tentang kebolehan melihat aurat calon istri dan konsep khiyar. Sementara 
Verifikasi Biologis Dan Kesehatan Reproduksi Calon Mempelai Pra Perkawinana Dalam Perspektif Hukum Islam

anggapan "tidak mungkin" dapat dengan mudah dipatahkan dengan merujuk kepada perkembangan teknologi dengan segala prestasi yang telah diraih.

Hadis Nabi yang menyatakan empat kriteria perempuan untuk dinikahi dapat dimaknai sebagai petunjuk bahwa seseorang yang akan menikah harus mengenal secara detail siapa perempuan yang bakal disuntingnya. ${ }^{16}$ Meski Hadis ini meletakkan laki-laki sebagai subyek dan perempuan sebagai obyek, namun tidak ada halangan untuk memaknainya secara terbalik. Sebagaimana laki-laki, perempuan juga seharusnya mengenal secara baik profil dan identitas laki-laki yang meminangnya. Empat kriteria yang disebutkan oleh Nabi dalam Hadis tersebut merepresentasikan semua hal penting dalam perkawinan, yakni aspek ekonomi (mal), romantisme (jamal), kedudukan sosial (nasab), dan moralitas (din). Dari sini dapat dikatakan bahwa segala bentuk verifikasi absah untuk dilakukan.

Konsep maqashid al-syari'ah dan hierarkinya jelas membuka jalan untuk menerima gagasan ini. Konsep ini mengenalkan lima almaqashid yang menempati posisi yang runut berdasarkan skala prioritas. Setiap al-maqashid memiliki tiga unsur yang juga menempati posisi berdasarkan skala prioritas. Dengan demikian, jika terjadi dua hal yang bertabrakan, pilihan harus jatuh berdasarkan skala prioritas. Dari sudut ini kita dihadapkan pada dua pilihan, yakni "melanggar larangan melihat aurat demi memelihara kesucian perkawinan", atau "mengindahkan larangan melihat aurat meski lembaga perkawinan terancam". Jika kita periksa posisi keduanya, mungkin kita sepakat bahwa memelihara kesucian perkawinan adalah pilihan lebih patut diprioritaskan.

Gagasan yang diusung dalam tulisan ini pada dasarnya hampir sama dengan pemikiran yang dikembangkan oleh para fukaha klasik. Apa yang mereka sebutkan sebagai alasan khiyar $^{17}$ dan fasakh ${ }^{18}$

\footnotetext{
${ }^{16}$ Terjemahan Hadis yang dimaksud sebagai berikut, "Perempuan itu dinikahi karena empat hal, yaitu: harta, keturunan, kecantikan, dan agamanya. Dapatkanlah wanita yang taat beragama, engkau akan berbahagia". Menurut Ibn Hajar al-Asqalanî, Hadis ini diriwayat oleh Bukhârî, Muslim, dan Imam yang lima (shahih); Ibn Hajar al-Asqalanî, Bulugh al- Maram, (Mesir: Mathba'ah al-Salafiyyah), h. 196.

${ }^{17}$ Pengertian khiyar menurut bahasa adalah memilih, sedangkan khiyar dalam jual beli menurut syara' ialah hak memilih bagi penjual atau pembeli untuk meneruskan akad jual beli atau membatalkannya. Hal ini agar kedua belah pihak (penjual dan pembeli) dapat memikirkan sejauh mungkin kebaikan kebaikan berlansungnya jual beli atau kebaikan untuk membatalkan jual beli, agar masing-
} 
Fitriyani

merupakan hal-hal yang digagas untuk diketahui melalui proses verifikasi. Perbedaannya hanya terletak pada momentum terungkapnya kekurangan yang dimiliki oleh salah satu pihak. Mereka mengandaikan sekiranya penyakit kusta, kudis, lepra, atau vagina tersumbat ditemukan setelah akad nikah, maka suami berhak memilih untuk bercerai atau melanjutkan perkawinannya. Sementara tulisan ini mengusulkan upaya untuk melakukan verifikasi atas semua itu sebelum perkawinan terjadi. Jika ditemukan maka tentu saja perkawinan yang direncanakan harus dibatalkan. Upaya mengetahui kekurangan-kekurangan itu sebelum akad lebih baik dibandingkan dengan membiarkan perkawinan terlanjur untuk kemudian diputuskan. Intinya adalah memindahkan momentum khiyar dari pasca nikah ke pranikah (antara lamaran dan akad).

Perbedaan identitas yang diketahui sebelum perkawinan dengan realitas yang ditemukan pada pasca perkawinan termasuk dalam bagian alasan yang dibenarkan untuk memilih perceraian. Analoginya, alasan perceraian juga memenuhi syarat untuk membatalkan perkawinan. Agar masalah tidak terlalu jauh, maka kemungkinan-kemungkinan yang dapat terjadi semestinya diverifikasi secara detail lebih awal. Jika merujuk pada nalar fikih yang mapan, ini pun selaras dengan kaidah menolak kerugian didahulukan daripada upaya meraih manfaat (dar'u al-mafasid muqaddam ala jalb al-mashalih). ${ }^{19}$

masing pihak tidak menyesal atas apa yang telaj dijualnya atau dibelinya. Sebab penyesalan tersebut bisa terjadi karena kurang hati-hati, tergesa-gesa, atau karena faktor-faktor lainnya. Hukum khiyar adalah boleh, sejauh memenuhi persyaratapersyaratan yang telah ditentukan, tetapi khiyar untuk menipu hukumnya haram dan dilarang. Sebagaimana Rasulullah saw., bersabda:

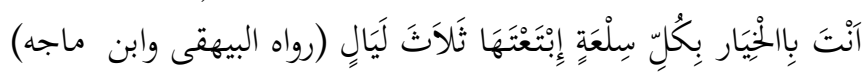

Artinya "Engkau berhak khiyar dalam tiap-tiap barang yang engkau beli selama tiga malam". (HR. Al-Baihaqy dan Ibnu Majah). http://www.ilmusaudara.com/2016/08/pengertian-khiyar-dalilhukumnya-macam.html

${ }^{18}$ Fasakha berasal dari bahasa Arab dari akar kata fa-sa-kha yang secara etimologi berarti membatalkan. Bila dihubungkan kata ini dengan perkawinan berarti membatalkan perkawinan atau merusak perkawinan. Dalam arti terminologis ditemukan berapa rumusan yang hampir sama maksudnya, diantaranya yang terdapat dalam KBBI, Pembatalan pernikahan oleh Pengadilan Agama berdasarkan tuntutan istri atau suami yang dibenarkan Pengadilan Agama atau karena pernikahan yang telah terlanjur menyalahi hukum pernikahan. Lihat Amir Syarifuddin, Hukum Perkawinan di Indonesia Antara Fikih Munakahat dan Undang-Undang Perkawinan, (Jakarta: Kencana, 2007), Cet. II, h. 242.

${ }^{19}$ Kaidah Ushul: "Dar'u al-mafasid muqaddam ala jalb al-mashalih " meraih yang maslahat dan menolak yang mafsyadat. Lihat H. A Djazuli Kaidah-Kaidah 
Verifikasi Biologis Dan Kesehatan Reproduksi Calon Mempelai Pra Perkawinana Dalam Perspektif Hukum Islam

Selain ditemukan alasan konseptual-akademis, kemajuan teknologi juga sangat memungkinkan untuk melakukan semua itu. Teknologi papsmir, misalnya, dapat mendeteksi kesehatan alat reproduksi seorang perempuan. Lebih dari itu, kondisi kemandulan lakilaki dan perempuan juga dapat diketahui melalui uji laboratorium atas sampel sperma dan ovum dengan dukungan perangkat-perangkat teknologi medis yang super canggih.

Cara pandang ini membuka peluang bagi para pihak yang terkait untuk mengembangkan aturan keperdataan Islam. Bukan hanya terbatas pada kepastian identitas laki-laki dan perempuan, bahkan berlanjut pada keperjakaan, keperawanan, kesehatan reproduksi, dan seterusnya. Pandangan ulama yang mengasumsikan pengungkapan kekurangan pasca perkawinan tidak terlepas dari perangkat teknologi pada masanya. Mereka tidak memiliki alat yang memadai untuk mengetahui kekurangan-kekurangan yang diderita oleh seseorang, sehingga potensi terungkapnya semua itu diserahkan pada fakta dan pengalaman empiris pasangan setelah perkawinan berjalan. Berbeda dengan sekarang, general chek up dapat mengungkap kondisi kesehatan seseorang secara menyeluruh dan detail. Hasil diagnosis dan general chek up tersebut kemudian dapat merekomendasikan dua hal. Pertama, larangan menikah manakala observasi medis menemukan larangan syar' $i$ bagi kedua mempelai untuk menikah seperti kesamaan jenis kelamin, banci/khuntsa, ${ }^{20}$ atau hubungan persaudaraan yang oleh syariah dinyatakan terlarang untuk menikah. Kedua, merekomendasikan khiyar, artinya kebebasan memilih untuk menikah atau tidak manakala ditemukan kekurangan-kekurangan yang tidak subtansial. Seorang lakilaki yang dinyatakan mandul, misalnya, tetapi dipastikan dapat melakukan panetrasi. Seorang perempuan yang ditemukan tidak virgin lagi dan bukan calon suaminya yang melakukan itu.

Hal yang menarik di dalam kitab fikih yang relevan dengan diskusi ini adalah pemikiran ulama yang memberikan kewenangan kepada pihak ketiga untuk menentukan kebenaran kekurangan/penyakit yang diklaim diderita oleh salah satu pihak. Dalam salah satu pendapat pihak ketiga yang dimaksud disebutkan secara jelas, yakni penguasa

Fikih, Kaedah Hukum Islam dalam Menyelesaikan Masalah-Masalah yang Praktis, (Jakarta: Kencana, 2011), Cet. IV, h. 6.

${ }^{20}$ Khuntsa adalah orang yang mempunyai dua alat kelamin, satu kelamin lakilaki dan satu kelamin perempuan atau hanya mempunyai satu lobang yang tidak menyerupai alat kelamin laki-laki maupun kelamin perempuan. Lihat http://www.fikihkontemporer.com/2013/04/khuntsa-waria-dalam-tinjauan-fiqih.html 
(sultan). Dalam konteks sekarang, pemikiran ini dapat dikembangkan bahwa pihak ketiga yang dapat dilibatkan dalam verifikasi adalah mereka yang memiliki kompetensi pada bidang yang diverifikasi. Boleh jadi melibatkan pakar patologi, pakar embriologi, ahli kebidanan, dan lain-lain. Penerapan verifikasi identitas biologis, sosiologis, dan kondisi kesehatan sebelum perkawinan dengan jelas mengokohkan pilar rumah tangga pasangan suami istri. Betapa tidak, pasangan yang dinyatakan lain untuk menikah adalah individu-individu yang tidak terikat dengan ikatan perkawinan dengan perempuan atau laki-laki lain, sehat jasmani baik laki-laki maupun perempuan.

Dihubungkan dengan masalah perkara lainnya, yakni perceraian, verifikasi identitas dipastikan memberi dampak positif. Berdasarkan data mengenai perceraian dan sebab-sebabnya, patut diduga bahwa ada sejumlah perceraian yang terjadi akibat dari tidak berjalannya verifikasi dengan baik. Sebagai contoh, poligami yang tidak sehat, tidak adanya keharmonisan dan tidak mampu menunaikan kewajiban sebagaimana mestinya. Alasan-alasan ini dirumuskan dengan bahasa yang tidak jelas. Pendalaman yang dilakukan melalui wawancara dengan hakim mengungkap bahwa tidak adanya keharmonisann itu dipicu oleh banyak hal, di antaranya salah satu pihak menderita mandul atau lakilaki impoten.

Selain itu, verifikasi dari aspek kesehatan juga memberi dampak positif untuk pencegahan penyebaran penyakit manular seksual. Dengan verifikasi melalui general chek up tentu saja kelayakan untuk menikah didasarkan pada sterilitas calon mempelai dari penyakit, terutama penyakit seks manular itu lebih baik untuk diketahui sebelum berlangsungnya pernikahan.

\section{Penutup}

Pemalsuan identitas biologis dalam perkawinan merupakan fenomena yang relatif baru, melengkapi fenomena pemalsuan identitas sosiologis yang telah terjadi sejak lama. Fenomena ini semestinya mendapatkan respons akademis mengingat ada sejumlah faktor yang membuka peluang terulangnya pemalsuan yang demikian dengan modus-modus yang sama atau lebih inovatif. Salah satu hal yang dapat dilakukan adalah membenahi sistem administrasi keperdataan Islam dengan memasukkan keabsahan melakukan verifikasi identitas biologis sebelum pernikahan manakala diperlukan. Bukan hanya itu, bentukbentuk lain harus dipikirkan untuk mengungkap pemalsuan dan 
kebohongan yang mungkin dapat dilakukan sebelum perkawinan. Gagasan verifikasi identitas biologis dan sosiologis sebelum perkawinan boleh dilakukan berdasarkan pemahaman kontekstual atas sejumlah Hadis Nabi dan pengembangan pemikiran para fukaha klasik terutama

Elaborasi yang mereka lakukan mengenai konsep khiyâr. Apa yang mereka sebut sebagai alasan khiyâr merupakan hal-hal yang digagas oleh tulisan ini untuk diketahui sebelum perkawinan. Pelaksanaan verifikasi identitas biologis dan beberapa hal yang terkait seperti kesehatan dan fungsi reproduksi kini mungkin dilakukan melalui uji laboratorium dengan bantuan perangkat teknologi canggih. Hal ini sangat wajar, sebab pemalsuan-pemalsuan yang mereka lakukan terkadang didukung oleh teknologi. Ketika kejahatan dilakukan dengan bantuan teknologi canggih, semestinya hukum memberi kewenangan untuk mengatasinya dengan teknologi yang minimal setara. Verifikasi identitas biologis yang dilakukan sepaket dengan verifikasi hal-hal lain yang terkait dengan organ reproduksi tidak hanya memelihara kesucian perkawinan tetapi juga berdampak pada semakin kuatnya pilar rumah tangga, yakni dengan memastikan bahwa pihak yang membangun rumah tangga adalah pihak yang laik secara jasmaniah, termasuk kondisi kesehatan yang bebas dari penyakit manular seksual.

\section{Daftar Pustaka}

Al-Jauzairi Abdul al-Rahman, Al-Fiqh 'Ala Mazahib al-Arba'ah, jilid 4 Bairut: Lubanan, 1990.

Amin Suma Muhammad. Hukum Keluarga Islam di Dunia Islam, Jakarta: Rajawali Perss 2004.

Amir Muallim dan Yusdani, Konfigurasi Pemikiran Hukum Islam, Yogyakarta: UII, 1999.

Ananda Arfa Faizal dan Watni Marpaung, Metodologi Penelitian Hukum Islam, Cet. I; Jakarta Kencana, 2016.

Connaly Peter, Aprproaches to The Study of Religion diterjemahnkan oleh Imam Khoiri, Aneka Pendekatan Studi Islam, Cet. I; Yogyakarta: LKiS, 2002.

Ghanduri Ahmad, al-Ahwal al-Syahshiyah fi Tasyri al-Islami, Cet. IV; Beirut: Maktabah al-Falah, 2001.

Djazuli Kaidah-Kaidah Fikih, Kaedah Hukum Islam dalam Menyelesaikan Masalah-Masalah yang Praktis, Cet. IV; Jakarta: Kencana, 2011. 
Hasan Ayyub Syaik, Fiqh as-Syariat Muslimat, penerjemah: Abdul Gofar EM, Fiqh Keluarga, Cet. VII; Jakarta: Pustaka AlKautsar, 2011.

Husain Munawwar, Said Agil dan Abdul Mustaqim, Studi Kritis Hadis Nabi Pendekatan Sosio Historis Kontekstual Asbabul Wurud, Cet. I; Yogyakarta: Pustaka Pelajar, 2001.

http://regional.liputan6.com/read/3084644/pernikahan-sejenis-yang menghebohkan-di-berbagai-daerah

http://www.fikihkontemporer.com/2013/04/khuntsa-waria-dalamtinjauan-fiqih.html

http://www.ilmusaudara.com/2016/08/pengertian-khiyardalilhukumnya-macam.html

http://www.landasanteori.com/2015/09/pengertian-gay-jenis-tipehubungan.html

http://www.resep.web.id/kehamilan/apa-yang-dimaksud-denganmandul.htm.

http://www.tribunnews.com/regional/2017/09/29/hal-seputarpernikahan-sejenis-di-bulukumba-jeritan-malam-pertamahingga-uang-panaik-puluhan-juta?page $=2$

https://id.wikipedia.org/wiki/Penelitian_eksploratif.

https://news.okezone.com/read/2017/09/29/337/1785268/catat-komnasperempuan-pernikahan-sejenis-di-indonesia-langgar-uuperkawinan.

Ibn Hajar al-Asqalanî, Bulugh al- Maram, Mesir: Mathba'ah alSalafiyyah

Ibn Khaldun dan Abu Rahman, Muqaddimah, Mesir: Dar al-Fikr, tt.

J.N.D Aderson, Islamic law in Modern World, New York: New York University Press, 1975.

J.S dan Sutan Mohammad Zain, Kamus Bahasa Indonesia, Cet. I; Jakarta: Pustaka Sinar Harapan 2001.

Kaelan M.S., Metodologi Penelitian Agama, Kualitatif Interdisipliner. Cet. I; Yogyakarta: Pradigma, 2010.

Lexy J Moleong,. Metodologi Penelitian Kualitatif, Bandung: PT. Remaja Rosdakarya 2009.

Majalah Peradilan Agama, Penegakan Hukum Keluarga di Indonesia, edisi 7 Oktober 2015.

Mardani, Hukum Keluarga Islam di Indonesia, Cet. I; Jakarta: Perenada Media Group, 2016. 
Marwan dan Jimmy, Kamus Hukum, Cet. I; Surabaya: Reality Publisher, 2009.

Maulidi, Teori Kemaslahatan dan Konstribusinya dalam Membangun Hukum Islam, yang dirangkum dalam kumpulan artikel Annual Internasional Conference on Islamic Studies AICIS 2016, The 16 Tahun Annual Internasional Conference on Islamic Studies IAIN Raden Intan Lampung, November 1-4 2016.

Mesra Alimin dan Euis Nurlaelawati, Potret Administrasi Keperdataan Islam di Indonesia, Cet. 1; Jakarta: Orbit Publishing, 2013.

Mesra Alimin, Verifikasi Identitas Biologis Menjelang Perkawinan dalam Presfektif Fikih. Jurnal Hukum Islam Fakultas Syariah UIN Syarif Hidayatullah Jakarta: Ahkam Vol XII, No. 2 Juli, Tahun 2012.

Mudzhar Atho dan Muhammad Maksum, Fikih Responsif Dinamika Integrasi Ilmu Hukum, Hukum Ekonomi dan Hukum Keluarga Islam, Cet. I; Jakarta: Pustaka Pelajar, 2017

Nasution Kaharuddin, Status Perempuan di Asia Tenggara: Studi Terhadap Undang-undang Perkawinan Muslim Kontenporer di Indonesia dan Malaisya, Leiden-Jakarta: INIS, 2002.

Khoiruddin Nasution: Arah Pembangunan Hukum Keluarga Islam AsySyir'ah, Jurnal Ilmu Syari'ah dan Hukum Vol. 46 No. I, Januari-Juni 2012.

Nazir Moh, Metodologi Penelitian, Cet. III; Jakarta: Gralis Indonesia, 1988.

Nurlelawati Euis, Modernization Tradition and Identity: The kompilasi Hukum Islam and Legal Practice in The Indonesian Religious Courts. Desertasi Doktor, Leiden Univerty, 2007.

Rasjid Sulaiman, Fiqh Islam, Bandung: Sinar Baru Algesindo, 2007. https://id.wikipedia.org/wiki/LGBT.

Santoso, Hakikat Perkawinan Menurut Undang-Undang Perkawinan, Hukum Islam dan Hukum Adat, Jurnal YUDISIA, Vol. 7, No. 2, Desember 2016.

Syafe'i, Ilmu Ushul Fiqih, Jakarta: Pustaka Setia, 2011.

Syarifuddin Amir, Hukum Perkawinan di Indonesia Antara Fiqh Munakahat dan Undang-Undang Perkawinan, Cet. II; Jakarta: Kencana, 2007.

Undang-Undang No. 1 Tahun 1974 tentang Perkawinan dilengkapi dengan Kompilasi Hukum Islam, Cet; tt: WIPRESS, 2007. 
Fitriyani

Zayd Mushthafa , al-Mashlahah fi at-Tasyri ' al-Islami Najm ad-Din atTufi , Kairo: Dar al-Fikr al-’Arabi, 1964. 